\title{
A Case of Fatal Late Vasospasm in a Patient with a Recurrent, Supratentorial Rhabdoid Primitive Neuroectodermal Tumor: Possible Molecular Implications
}

\author{
Tekrarlayan Supratentoriyal, Rabdoid PrimitifNöroektodermal \\ Tümörlü Bir Hastada Ölümcül Geç Vazospazm Olgusu: \\ Olası Moleküler Yansımalar
}

\author{
Massimo MISCUSI ${ }^{1}$, Luca De MARTINO ${ }^{2}$, Manila ANTONELLI ${ }^{3}$, Giorgio MANGINO ${ }^{1}$, Luca RICCIARDI ${ }^{1}$, \\ Gianpaolo SPINELLI ${ }^{1}$, Stefano FORCATO ${ }^{2}$, Antonella CALOGERO ${ }^{1}$, Vincenzo PETROZZA ${ }^{1}$, \\ Giuseppe RAGONA ${ }^{1}$, Antonino RACO 1 \\ ${ }_{1}^{1}$ Sapienza University of Rome, Medico-Surgical Sciences and Biotechnologies, Latina, Italy \\ ${ }^{2}$ Sapienza University of Rome, NESMOS, Rome, Italy \\ Sapienza University of Rome, Department of Pathology, Rome, Italy
}

Corresponding Author: Massimo MISCUSI / E-mail: massimo.miscusi@uniroma1.it,m.miscusi@libero.it

\begin{abstract}
We report the case of a 44-year-old man who experienced a fatal and untreatable delayed vasospasm after resection of a recurrent temporal IV grade primitive neuroectodermal tumor (PNET). The histological analysis demonstrated a rare rhabdoid variant of the tumor with a diffuse myxoid degeneration; molecular investigations demonstrated an upregulation of IL-1 $\beta$ and IL- 6 expression in the recurrence.

We reviewed the pathophysiology of the vasospasm that occurs after tumors resection, and due to the rarity of case, we speculated on the possibility that specific histological and molecular features of the tumor could have contributed to the delayed and fatal complication.

KEYWORDS: PNET, Rhabdoid cells, Complication, Cerebral ischemia, Vasospasm

öz

Tekrarlayan temporal evre IV primitif nöroektodermal tümörün (PNET) rezeksiyonu sonrasında ölümcül ve tedavi edilemeyen gecikmiş vazospazm yaşayan 44 yaşında bir erkeği bildiriyoruz. Histolojik analiz difüz miksoid dejenerasyonlu nadir bir rabdoid tümör varyantı gösterdi; moleküler incelemeler nükste IL-1 $\beta$ ve IL- 6 ekspresyonunun arttığını gösterdi.

Tümör rezeksiyonunda oluşan vazospazmın patofizyolojisini gözden geçirdik ve bu olgunun nadirliği nedeniyle tümörün spesifik, histolojik ve moleküler özelliklerinin bu geç ve ölümcül komplikasyona katkıda bulunmuş olabileceğini değerlendirdik.
\end{abstract}

ANAHTAR SÖZCÜKLER: PNET, Rabdoid hücreler, Komplikasyon, Serebral iskemi, Vazospazm

\section{INTRODUCTION}

Postoperative vasospasm is a rare complication that may follow a cerebral tumor resection; it is seldom reported in the literature. According to a very recent review, only 56 cases have been reported since the first cases in $1960(2,13)$.

The literature highlights two common denominators in patients that developed cerebral vasospasm after resection of a tumor (18). The first is a surgery that involves manipulation and dissection around an artery; the second is a blood spill into the subarachnoid space. Indeed, all the previously reported cases involved tumors in the proximity of the basal subarachnoid space or surgical approaches that allowed blood to accumulate in a specific pattern in the basal cisterns.
In the vast majority of cases, these tumors were dermoid cysts, pituitary adenomas, craniopharyngiomas, astrocytomas, neuromas, or meningiomas.

Intriguingly, to date, only two cases of vasospasm have been described in association with embryonal tumors. One concerned a cerebello-pontine angle, primitive neuroectodermal tumor (PNET) that occurred in a child; the other was an esthesioneuroblastoma in an adult patient.

Reports on atypical cases can be of great value for the etiological definition of tumor-associated vasospasm. To that end, this study describes an adult case of a fatal, delayed vasospasm after resection of a recurrent, grade IV, temporal PNET. 
Due to the rarity of case, we speculated on the possibility that specific molecular features of the tumor could have contributed to the delayed and fatal complication.

Therefore, we investigated IL-1 $\beta$, IL- 6 and TNF-alpha mRNA expression levels both in the primary tumor and the recurrence as these have been previously associated with the occurrence of vasospasm and poor clinical outcome after spontaneous subarachnoid hemorrhage (SAH).

\section{CASE REPORT}

\section{History}

A 44-year-old man had undergone surgery for a recurrent, grade IV, right temporal PNET, one year after surgical intervention to remove the primary tumor (Figure 1A). Prior to the second intervention, the patient's neurological condition was unremarkable. The preoperative MRI did not reveal any signs of ischemic lesions after the first surgery. After reopening the previous craniotomy, a right temporal lobectomy was performed with radical excision of the recurrent tumor (Figure 1B). As in the first operation, this presented a clear cleavage plane from normal brain.

\section{Postoperative Course}

The postoperative course was uneventful. The patient was discharged on postoperative day 8 . His general physical and neurological condition was normal. Fifteen days later, the patient returned to the hospital with left hemiparesis, following a sudden, transitory loss of consciousness. A CT scan revealed a hypodense lesion involving the residual posterior portion of the right temporal lobe, which suggested an ischemic insult due to a late vasospasm. The suspected vascular insult was attributed to the manipulation of the right middle cerebral artery complex at the time of the intervention (Figure 1C).The patient was discharged to a rehabilitation unit. After slow, progressive improvement, the patient suddenly experienced a worsening of neurological status one month after the surgery and entered a comatose state. He was then readmitted to the intensive care unit of our Department but his neurological condition deteriorated progressively, with a fixed right anisocoria. A CT scan confirmed the spread of the lesion to several hypodense areas involving both hemispheres (Figure 1D). An MRI revealed a bilateral cerebral ischemia, that was diffuse throughout the brain, brain stem, and cerebellum (Figure 2A,B). There was no evidence of intracranial or

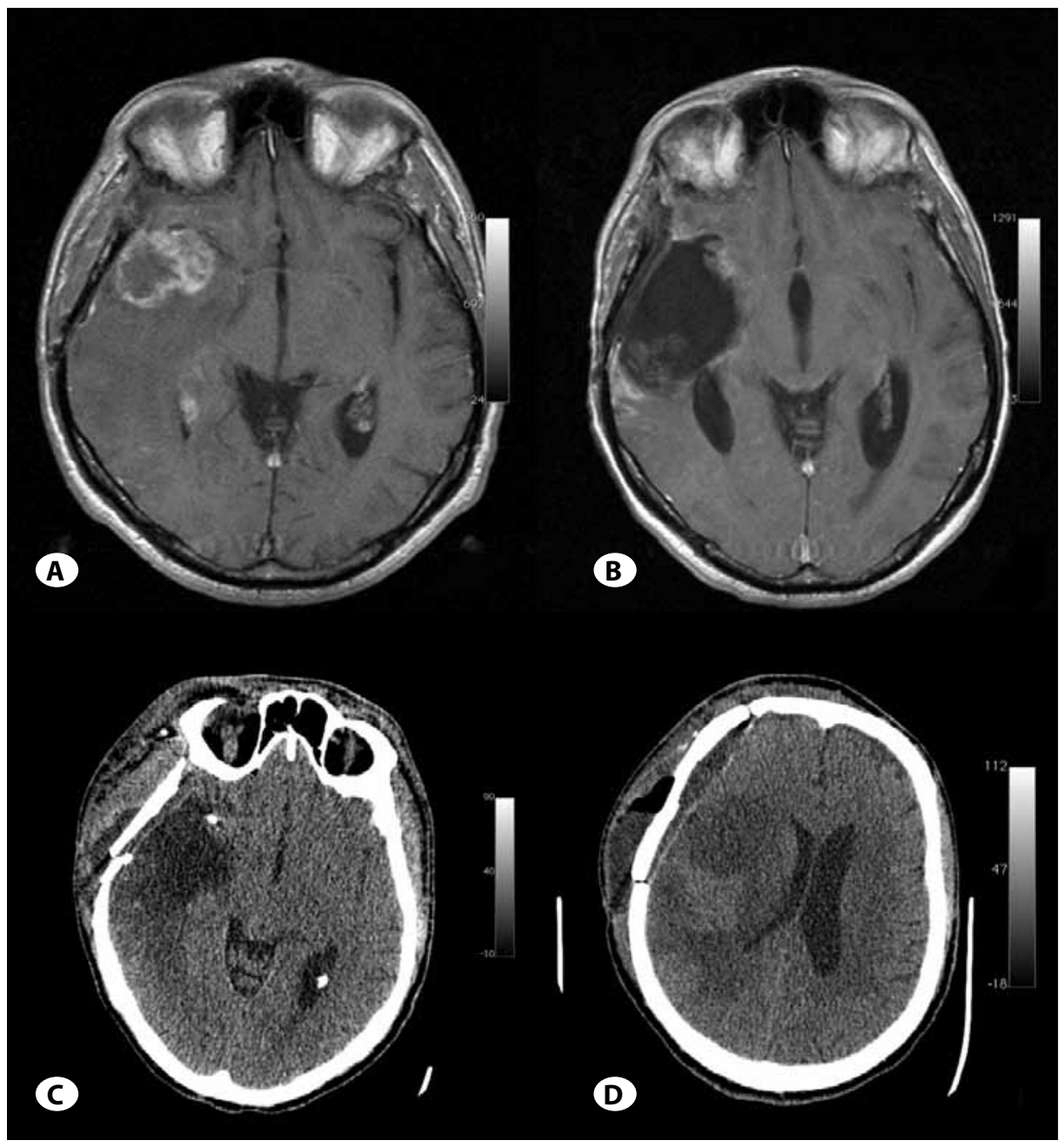

Figure 1: Surgical removal of recurrent PNET and postoperative cerebral ischemia.

Images of a recurrent, grade IV, right temporal, primitive neuroectodermal tumor (PNET), one year after surgical intervention of the primary tumor. A) Preoperative MRI scan; axial T1 with gadolinium shows the recurrent PNET in the temporal region. B) Early postoperative MRI scan; axial T1 with gadolinium demonstrates the radical resection of the temporal lesion, without signs of ischemic complications. C) Axial CT scan, performed 15 days after the operation, reveals a hypodense lesion that involves the residual posterior portion of the right temporal lobe. D) Axial CT scan performed one month after the operation shows the spread of the lesion to several hypodense areas involving both hemispheres. 
epiaortic thrombosis, but an angiographic MRI showed a diffuse reduction of cerebral perfusion (Figure $2 C, D$ ). The diffuse intracranial vasospasm did not respond to medical therapy, and the patient died 7 days after rehospitalization.

\section{Pathological and Molecular Findings}

Histological analysis of tumor samples excised from the primary and recurrent sites showed the presence of nests of atypical cells with hyperchromatic, sometimes vacuolated, lobated nuclei. Areas with glandular and squamous characteristics were present in both tumors, showing myxoid degeneration (Figure 3A, B). Rhabdoid-like, epithelialmesenchymal antigen-negative cells with an eosinophilic cytoplasm were frequently observed. When found in the primary tumor, these cells were positive for integrase interactor 1 (INI1), a marker for malignant rhabdoid tumors and epithelioid sarcomas. A focal positivity for GFAP was also exclusively found in specimens from the primary tumor (Figure 3C). Additional features common to both tumor types were the presence of cytokeratin-positive metaplastic areas and a diffuse, positive stain for vimentin in all cells (Figure 3D).
Notably, the recurrent tumor tissue showed a high density of the above additional features. According to the WHO classification, a central nervous system PNET, grade IV was diagnosed.

We then investigated whether the postoperative vasospasm was related to the production of vasoactive molecules, including interleukin-beta (IL-1 $\beta$ ), IL-6, and tumor necrosis factor alpha (TNFa). According to Mangino et al., we used real-time PCR to compare expression levels in the recurrent tumor tissue and the primary tumor (Figure 4) (16). The gene for GPDH was chosen as an internal control and standard reference. The expression of IL-1 $\beta$ was about seven-fold higher $(p<0.001)$ in the recurrent tumor compared to the primary tumor. This expression was also high compared to that observed in a grade IV glioblastoma and in a normal brain sample. The IL-6 levels were upregulated in all the studied types of tumors compared to the normal brain sample $(p<0.01)$, with no significant differences among the tumors. Finally, the level of TNFa expression was very similar between the tumor samples and the normal control.

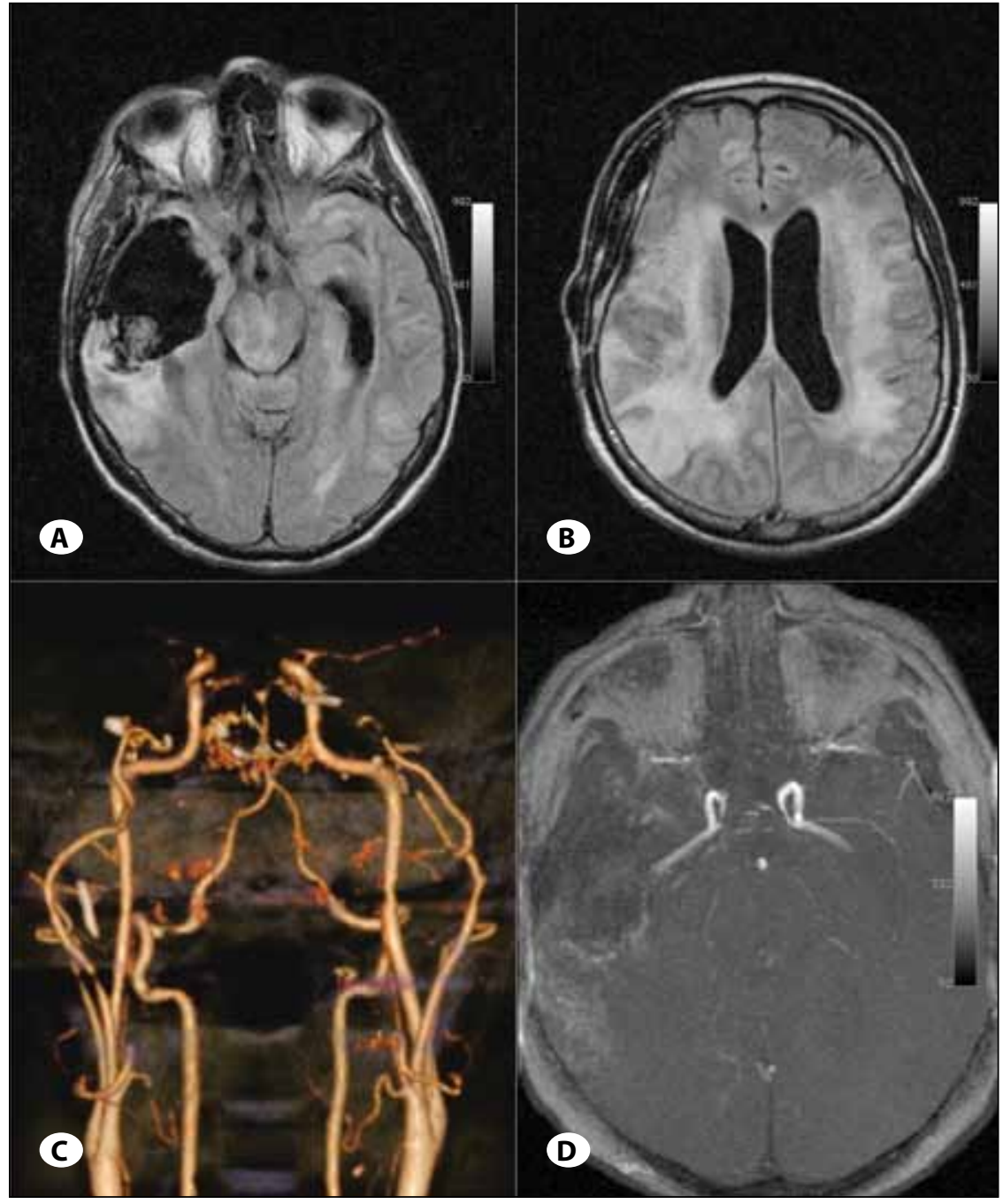

Figure 2: Postoperative MRI

MRI images show cerebral ischemia detected one month after excision of the recurrent tumor. A,B) Axial Flair MRI scan reveals bilateral cerebral ischemia, diffuse throughout the brain, brain stem, and cerebellum; C) 3D reconstruction from a CT scan with contrast shows the absence of intracranial or epiaortic thrombosis; D) Axial angiographic-MRI demonstrates a diffuse reduction of cerebral perfusion. 

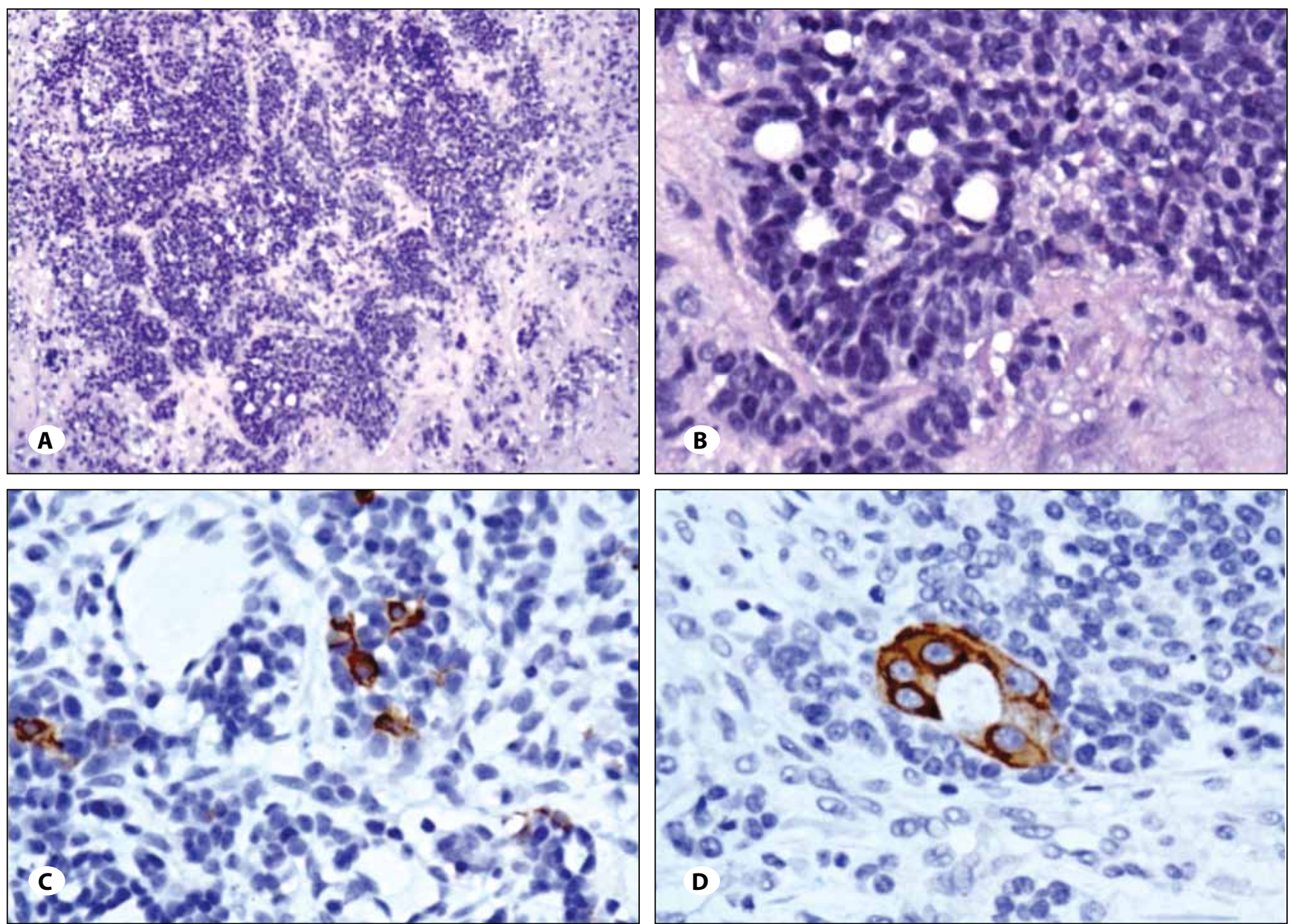

Figure 3: Immunohistochemistry of tumor sections. A, B) The neoplasm formed glandular and squamous areas and shows myxoid degeneration (A, x40; $B, x 200)$; C) focal positivity of neoplastic cells stained for GFAP (x200); D) metaplastic area shows cytokeratin immunostain (x400).

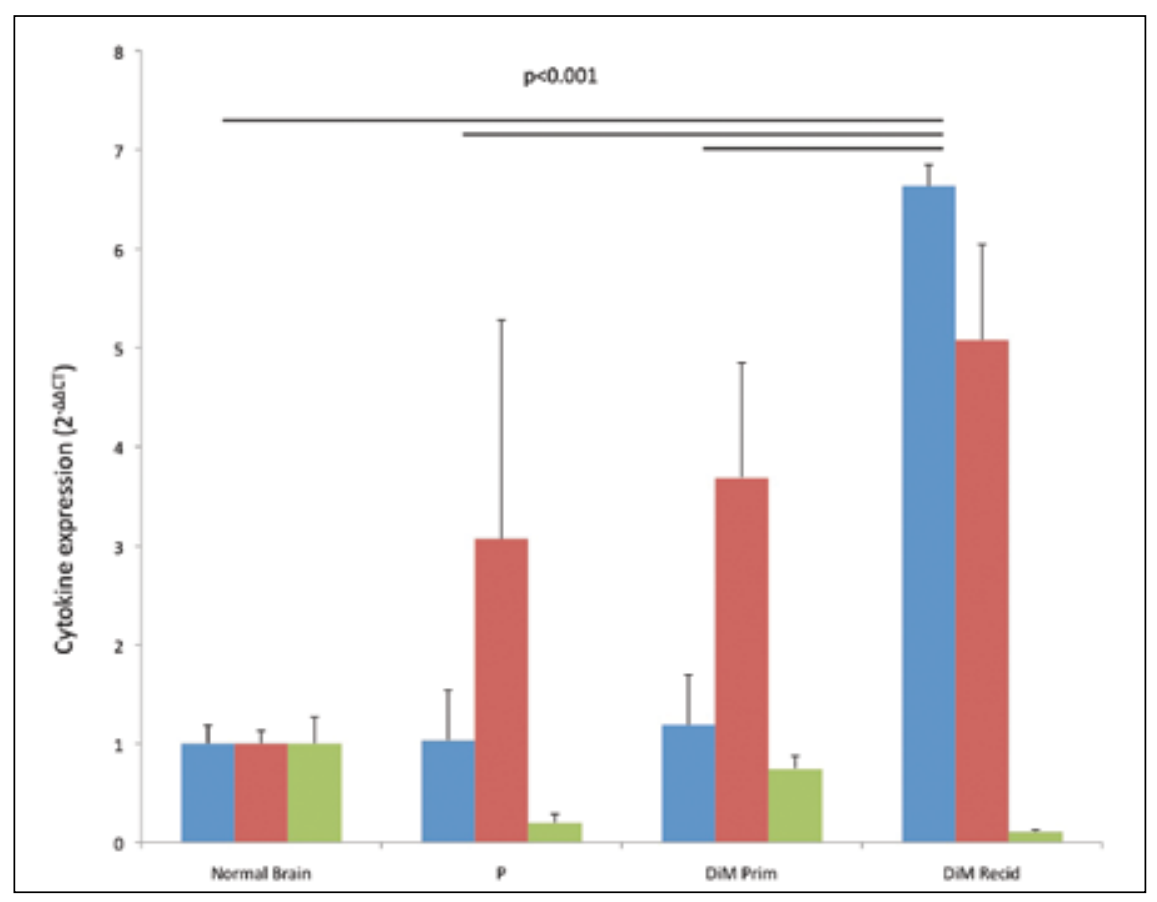

Figure 4: Cytokine mRNA expression in tumor cells and normal brain cells. Total cellular RNA was isolated, and real time RT-PCR was performed, according to the Mangino et al methods. Relative mRNA expression was evaluated with the $2^{-\Delta \Delta C T}$ method, compared to levels measured in normal brain, and calibrated with GAPDH as an internal control. Significant differences were determined with an ANOVA analysis and a Bonferroni posthoc test. Blue bars: IL-1 $\beta$; red bars: IL-6; green bars: TNFa. The recurrent tumor (Dim Recid) showed highly significantly different IL-1 $\beta$ mRNA levels compared to the primary tumor (Dim Prim), a grade IV glioma sample $(P)$, and the normal brain sample $(p<0.001)$. Both IL-6 and TNFa mRNA levels were significantly different between the recurrence (Dim Recid) and the normal brain sample; $p<0.01$. 


\section{DISCUSSION}

An atypical vasospasm following a tumor resection was first reported by Krayenbuehl in 1960, who described a vasospasm attributed to postoperative bleeding after resection of a pituitary neoplasm (13).

According to Origitano, vasospasm secondary to a tumor resection has two common denominators: manipulation and dissection of the Willis circle arteries and intraoperative SAH (19). In the first case, the vasospasm would be triggered mechanically by the surgeon, and in the second case, it would result from the vasoactive effect of hemoglobin metabolites, as in the case of an aneurysmal SAH. Indeed, the majority of cases in the literature concern tumors in proximity to the basal cisterns or surgical procedures that have allowed blood to accumulate around the major cerebral vessels in the basal cisterns $(2,7,22)$. In most previously reported cases, neurological deterioration occurred between 5 and 10 days after resection of the tumor. This supported the hypothesis that vasospasm might arise from the same mechanisms postulated to cause an aneurysmal SAH. Moreover, according to this hypothesis, it has been speculated that the amount of intraoperative bleeding and the thickness of cisternal clotting may also be critical variables in case of vasospasm secondary to tumor resection (5).

Vasospasm due to tumor resection is comparatively rare. The occurrence may be explained by specific cofactors that contribute to the onset of this complication. The nature of cofactors might be related to the specific tumor involved, the expressed phenotype, or the level of interaction with the microenvironment of the tumor. However, previous investigations in patients affected by episodes of vasospasm after tumor resection did not result in a clear understanding of the kind of cofactors that might be involved. Some authors have therefore suggested alternative and specific explanations for the pathophysiology of vasospasm associated with tumor resection.

To explain the occurrence of cerebral arterial vasospasm, some authors have implicated hypothalamic dysfunction at the time of surgery, which led to subsequent hyperactivity of the sympathetic nervous system and increased levels of circulating catecholamines $(23,24)$. This hypothesis was favorable in cases of pituitary and suprasellar tumors, although the evidence for hypothalamic dysfunction was detected in only a portion of those cases and only after the development of a vasospasm (5).

Others hypothesized that vasospasm could be caused by the placement of gel foam in the tumor bed at the time of surgery and an imbalance of vascular tone that resulted from the stress of surgery $(4,5,17)$.

Nevertheless, a burgeoning body of evidence has suggested that various constituents of the inflammatory response, including adhesion molecules, cytokines, leukocytes, immunoglobulins, and complement, may be critical in the pathogenesis of cerebral vasospasm $(8,17)$. Vasoactive elements are frequently liberated from the tumor bed, either at the time of surgery, or later, when portions of the tumor have undergone necrosis. The diffusion of these substances into the basal subarachnoid spaces might lead to a vasospasm $(3,17)$.

Interestingly, both in vitro and in vivo studies have associated cytokines, such as TNFa, IL- 6 and IL-1 $\beta$ with vasospasm, $\mathrm{SAH}$, and poor outcome. These cytokines have been reliably detected in the cerebrospinal fluid and microdialysate from patients with $\mathrm{SAH}$, and they were associated with vasospasm (evidenced by transcranial Doppler ultrasound), poor outcome, and ischemic deficits $(6,9,10-12,18,20)$.

The present case is the first reported adult case of a late, bilateral, diffuse vasospasm that occurred after the resection of a recurrent embryonal neoplasm to our knowledge; this vasospasm was associated with $m$-RNA hyperexpression of three of the most vasoactive cytokines, IL-1 $\beta$, IL-6, and TNFa.

Our tumor presented high levels of IL- 6 and IL- $1 \beta$ mRNA both at first presentation and recurrence but TNFa m-RNA levels were comparable to those found in normal brain. Interestingly, IL-1 $\beta$ m-RNA was seven-fold higher in the recurrent tumor and it could have triggered the fatal vasospasm.

The vasospasm could also be related to the embryonal nature of the tumor. To date, only two cases of embryonal tumors have been described. In the study of Almubaslat and Africk, the authors did not advance any particular hypothesis for the cause (1) In the second study, a diffuse, cerebral vasospasm was described in a child with a posterior fossa PNET. The tumor presented diffuse rhabdoid elements released into the tumor bed and these elements were postulated to cause an autoimmune-type response that led to the vasospasm (15) According to those authors, an antibody response to cellular antigens exposed on rhabdoid elements of the tumor was diverged toward the cerebral vasculature, with damage of the tissue. Thus, they invoked an autoimmune mechanism to explain the vasospasm. However, that hypothesis was not supported by evidence from that study.

Indeed, several cytokines including IL- 6 and TNFa can be released by rhabdoid tumors and these cytokines have recently been implicated in autoimmune mechanisms (22). However, the tumor mass described in this study exhibited rhabdoid-like elements that were positive for INI1, which ruled out a rhabdoid nature. We are tempted to speculate that the fascinating hypothesis raised by Lee et al. may not be exclusively associated with rhabdoid tumors, and may be applicable to other atypical tumors; thus, the hyperexpression of vasoactive cytokines may be a general feature of these tumors. However, this question requires further study as only $\mathrm{m}$-RNA expression cannot be exhaustive in sustaining such a hypothesis.

In the present case, the absence of blood in the basal cisterns in the early postoperative period, the timing of the vasospasm appearance, and the unresponsiveness to medical therapy, have led to a search for alternative mechanisms. 
Our hypothesis is that vasospasm may have been related both to a kind of tumor type-induced vasculitis, triggered by surgical intervention, or it may have been induced by a massive release of vasoactive cytokines, in particular IL-1 $\beta$, from residual necrotic tumor cells into the CSF during the days after the intervention.

Unfortunately, this is only a hypothesis based on clinical and immunohistochemical data, and further studies to understand this rare but potentially fatal phenomenon should be attempted $(3,17)$.

\section{CONCLUSIONS}

Postoperative vasospasm is a rare and severe complication after brain tumor resection and is general associated with postoperative subarachnoid haemorrhage in the basal cisterns or manipulation of the brain vessels in general. Interestingly, the rare rhabdoid variant of the PNET has been associated with postoperative vasospasm, and specific features of the reported cases seem to suggest a different pathophysiology. Autoimmune vasculitis or cytokine-induced mechanisms have been proposed in the literature as possible alternative explanations, and our report seems to confirm such a hypothesis. Further studies should be conducted to understand the pathophysiology of this rare but often fatal complication.

\section{REFERENCES}

1. Almubaslat $M$, Africk $C$ : Cerebral vasospasm after resection of an esthesioneuroblastoma: Case report and literature review. Surg Neurol 68(3):322-328, 2007

2. Alotaibi NM, Lanzino G: Cerebral vasospasm following tumor resection. J Neurointerv SurgJ Neurointerv Surg 5(5):413-418, 2013

3. Bejjani GK, Duong DH, Kalamarides M, Ziyal I, Sullivan BJ: Cerebral vasospasm after tumor resection: A case report. Neurochirurgie 43(3):164-168, 1997

4. Camp PE, Paxton HD, Buchan GC, Gahbauer H: Vasospasm after transsphenoidal hypophysectomy. Neurosurgery 7: 382-386, 1980

5. Chang SD, Yap OWS, Adler JR: Symptomatic vasospasm after resection of a suprasellar pilocytic astrocytoma: Case report and possible pathogenesis. Surg Neurol 51:521-527, 1999

6. Chou SH, Feske SK, Atherton J, Konigsberg RG, De Jager PL, Du $R$, Ogilvy CS, Lo EH, Ning M: Elevation of serum tumor necrosis factor- $a$ is associated with poor outcome in subarachnoid hemorrhage. J Investig Med 60(7):1054-1058, 2012

7. Cervoni L, Salvati M, Santoro A: Vasospasm following tumor removal: Report of 5 cases. Ital J Neurol Sci 17(4):291-294, 1996

8. Dumont AS, Dumont RJ, Chow MM, Lin CL, Calisaneller T, Ley KF, Kassell NF, Lee KS: Cerebral vasospasm after subarachnoid hemorrhage: Putative role of inflammation. Neurosurgery 53(1):123-133, 2003

9. Fassbender K, Hodapp B, Rossol S, Bertsch T, Schmeck J, Schütt S, Fritzinger M, Horn P, Vajkoczy P, Kreisel S, Brunner J, Schmiedek P, Hennerici M: Inflammatory cytokines in subarachnoid haemorrhage: Association with abnormal blood flow velocities in basal cerebral arteries. J Neurol Neurosurg Psychiatry 70(4):534-537, 2001
10. Hanafy KA, Grobelny B, Fernandez L, Kurtz P, Connolly ES, Mayer SA, Schindler C, Badjatia N: Brain interstitial fluid TNFalpha after subarachnoid hemorrhage. J Neurol Sci 291(12):69-73, 2010

11. Hendryk S, Jarzab B, Josko J: Increase of the IL-1 beta and IL-6 levels in CSF in patients with vasospasm following aneurysmal SAH. Neuro Endocrinol Lett 25(1-2):141-147, 2004

12. Jedrzejowska-Szypułka $H$, Larysz-Brysz $M$, Kukla $M$, Snietura M, Lewin-Kowalik J: Neutralization of interleukin-1beta reduces vasospasm and alters cerebral blood vessel density following experimental subarachnoid hemorrhage in rats. Curr Neurovasc Res 6(2):95-103, 2009

13. Krayenbuehl $\mathrm{H}$ : A contribution to the problem of cerebral angiospastic insult. Schweiz Med Wochenschr 90:961-965, 1960

14. LeRoux PD, Haglund MM, Mayberg MR, Winn HR: Symptomatic cerebral vasospasm following tumor resection: report of two cases. Surg Neurol 36(1):25 - 31, 1991

15. Lee TT, Ragheb J, Bruce JC, Altman N, Morrison G: Diffuse cerebral vasospasm with ischemia after of a cerebellopontine angle primitive neuroectodermal tumor in a child. Pediatr Neurosurg 29(6):300-303, 1998

16. Mangino G, Percario ZA, Fiorucci G, Vaccari G, Acconcia F, Chiarabelli $C$, Leone $S$, Noto A, Horenkamp FA, Manrique $S$, Romeo G, Polticelli F, Geyer M, Affabris E: HIV-1 Nef induces proinflammatory state in macrophages through its acidic cluster domain: Involvement of TNF alpha receptor associated factor 2. PLoS One 6(8):e22982, 2011

17. Mawk JR, Ausman J, Erickson DL, Maxwell RE: Vasospasm following transcranial removal of a large pituitary adenomas. J Neurosurg 50:229- 232, 1979

18. Nam DH, Kim JS, Hong SC, Lee WH, Lee Jl, Shin HJ, Park K, Eoh $\mathrm{W}$, Han $\mathrm{DH}$, Kim JH: Expression of interleukin-1 beta in lipopolysaccharide stimulated monocytes derived from patients with aneurysmal subarachnoid hemorrhage is correlated with cerebral vasospasm. Neurosci Lett 312(1): 41-44, 2001

19. Origitano TC, al-Mefty O, Leonetti JP, DeMonte F, Reichman $\mathrm{OH}$ : Vascular considerations and complications in cranial base surgery. Neurosurgery 35(3):351- 362, 1994

20. Osuka K, SuzukiY,TanazawaT,Hattori K, Yamamoto N,Takayasu M, Shibuya M, Yoshida J: Interleukin- 6 and development of vasospasm after subarachnoid haemorrhage. Acta Neurochir (Wien) 140(9):943-951, 1998

21. Provencio JJ, Vora N: Subarachnoid hemorrhage and inflammation: Bench to bedside and back. Semin Neurol 25(4):435-444, 2005

22. Rittierodt M, Tschernig T, Samii M, Walter GF, Stan AC: Evidence of recurrent atypical meningioma with rhabdoid transformation and expression of pyrogenic cytokines in a child presenting with a marked acute-phase response: Case report and review of the literature. J Neuroimmunol 120(12):129-137, 2001

23. Wilkins $\mathrm{RH}$ : Hypothalamic dysfunction and intracranial arterial spasms. Surg Neurol 4:472 -480, 1965

24. Wilson JL, Field JR: The production of intracranial vascular spasm by hypothalamic extract. J Neurosurg 40:473- 479, 1974 